\title{
Effects of Pseudomonas fluorescens on the Water Parameters of Mycorrhizal and Non-Mycorrhizal Seedlings of Pinus halepensis
}

\author{
José A. Domínguez-Núñez ${ }^{1, *}$, Daniel Muñóz ${ }^{1}$, Ana de la Cruz $^{2}$ and José A. Saiz de Omeñaca ${ }^{1}$
}

1 Departamento de Silvopascicultura. E.T.S.I. Montes and E.U.I.T. Forestal. Universidad Politécnica de Madrid Av/Ciudad Universitaria s/n. 28040, Madrid, Spain;

E-Mails: danielmuozmate@yahoo.es (D.M.); joseantonio.saizdeomenaca@upm.es (J.A.S.O.)

2 Departamento de Protección Forestal. CIFOR-INIA (Instituto Nacional de Investigaciones y Tecnología Agrarias). Ctra. Coruña, Km. 7, 28040, Madrid, Spain; E-Mail: calleja@inia.es

* Author to whom correspondence should be addressed; E-Mail: josealfonso.dominguez@upm.es; Tel.: +34-913-367-103; Fax: +34-913-365-568.

Received: 9 May 2013; in revised form: 2 August 2013 / Accepted: 2 August 2013/

Published: 20 August 2013

\begin{abstract}
Inoculation of forest seedlings with mycorrhizal fungi and rhizobacteria can improve the morphological and physiological qualities of plants, especially those used for regeneration of arid areas. In this paper, under standard nursery conditions, Aleppo pine seedlings were inoculated with Pseudomonas fluorescens CECT 5281 rhizobacteria. Some of these seedlings were also inoculated with the ectomycorrhizal fungus Pisolithus tinctorius. Five months after the inoculations, we examined the growth, water parameters (osmotic potential at full turgor [ $\Psi \pi f u l l]$, osmotic potential at zero turgor [ $\Psi \pi 0]$, and the tissue modulus of elasticity near full turgor $\left[\mathrm{E}_{\mathrm{max}}\right]$ ), mycorrhizal colonisation, and concentration of macronutrients (N, P, K, Ca and $\mathrm{Mg}$ ) in the seedlings. Subsequently, a trial was conducted to assess the root growth potential. P. fluorescens CECT 5281 decreased the cellular osmotic potential of $P$. halepensis seedlings but increased its elasticity. $P$. tinctorius $+P$. fluorescens caused osmotic adjustment at zero turgor and increased tissue elasticity, which improved tolerance to water stress. All inoculations improved the growth and nutrition of the seedlings but caused non-significant effects on root growth potential. The co-inoculation Pisolithus tinctorius + Pseudomonas fluorescens at the nursery may be a suitable technique for producing improved seedling material for restoration purposes.
\end{abstract}


Keywords: rhizobacteria; osmotic adjustment; elastic adjustment; Pisolithus tinctorius; Pinus halepensis

\section{Introduction}

In semiarid Mediterranean ecosystems, water and nutrient availability are the primary limiting factors for plant productivity and for the diversity of microflora associated with the roots of plants [1]. Consequently, forest species of the Mediterranean area often exhibit different strategies of water use in response to drought [2].

Aleppo pine is one of the most common tree species in the Mediterranean area, and it has been one of the most frequently used species in the reforestation of degraded areas [3]. Numerous studies have been conducted with the aim of improving the quality of seedlings produced in nurseries [4]. Among the cultural practices utilised, inoculation with ectomycorrhizal fungi and plant growth promoting rhizobacteria (PGPR) has shown promise for improving the quality of seedlings and increasing their survival in plantations, especially in soils with low microbial activity [5].

Pisolithus tinctorius is an ectomycorrhizal fungus that has been widely used in reforestation programs since the 1970s. Its potential for cultivation and inoculation, along with the great diversity of plant species it associates with, are promising features for its study and application in improving the quality of forest plants. There have been a wide range of studies on the positive effects of Pisolithus tinctorius on the growth of plants; of particular interest are studies that examine its ability to enhance access to certain nutrients, such as phosphorus [6] and nitrogen [7,8], and its ability to reactivate soil microbiological activity [9]. The interaction of Pisolithus spp. with angiosperms and gymnosperms may reduce a host's water deficit under drought conditions [10]. Therefore, $P$. tinctorius is viewed as a suitable fungus for restoring vegetation in arid or semiarid environments, especially in combination with organic soil amendments [11].

Pseudomonas fluorescens is a PGPR bacterium that is capable of colonising a wide range of ecological niches, especially the rhizosphere of plants [12]. P. fluorescens promotes plant growth by producing phytohormones such as auxin (IAA), gibberellins and cytokinins, as well as specific amino acids and other growth promoters [13]. It also has a high capacity for phosphate solubilization, and is able to produce siderophores [14]. Also, certain strains of Pseudomonas fluorescens promoting the ACC deaminase activity, helping the plant to better resist the stress, including drought [15]. Adherence and colonisation of MHB (mycorrhizal helper bacteria) such as P. fluorescens on the surface of some ectomycorrhizas can affect and improve the symbiotic relationship between the plant and the ectomycorrhiza, and thus benefit the host plant [16]. Potential MHB mechanisms affecting the establishment and function of mycorrhizal symbiosis include the stimulation of spore germination, mycelial growth, promotion of root-fungus contact or stimulation of potential mycorrhizal short root production [17].

Our initial hypothesis was that $P$. fluorescens CECT 5281 would have synergistic effects and could positively influence physiology of $P$. tinctorius mycorrizal seedlings. In the present study, Aleppo pine seedlings were co-inoculated with the mycorrhizal fungus Pisolithus tinctorius and the rhizobacterium 
Pseudomonas fluorescens CECT 5281. The aim was to determine the specific effects of Pseudomonas fluorescens on certain water parameters that characterize the quality of mycorrhizal and non-mycorrhizal seedlings of Pinus halepensis used for reforestation. We analyzed the osmotic potential at full turgor $\left(\Psi \pi_{\text {full }}\right)$ and zero turgor $\left(\Psi \pi_{0}\right)$, and the modulus of elasticity near full turgor $\left(\mathrm{E}_{\max }\right)$. Additionally, we studied the effect of the inoculations on growth, nutrient uptake, mycorrhizal colonisation, and root growth potential of the seedlings.

\section{Results and Discussion}

Pseudomonas fluorescens is a plant growth stimulator that efficiently promotes seed germination, accelerates growth in early stages, induces root initiation, increases the formation of roots and root hairs, and controls pathogens in some forest species [18]. The mycorrhizal fungus Pisolithus tinctorius is also known to improve plant growth and nutrition in some cases, particularly for Pinus halepensis [19]. In general, the association of mycorrhizal fungi with Pseudomonas sp. can promote plant growth [16], especially in roots. However, Pisolithus sp. and PGPR are not always positively synergistic in the promotion of plant growth [20]. Previous research has highlighted the importance of the interaction between Pseudomonas fluorescens and Pisolithus tinctorius [21] and illustrated its positive effect on the growth of Pinus halepensis [22]. This effect occurs due to the mobilisation of phosphorus by the fungus, combined with the mineralising activity, activity of growth-promoting hormones, and anti-pathogenic activity of the bacteria.

In the present study, both $P s$ inoculation and $P s \times P t$ co-inoculation improved most of the growth parameters (Table 1). The $P s$ inoculation significantly increased the root dry weight to a greater extent than the $P s \times P t$ co-inoculation; however, the $P s \times P t$ co-inoculation significantly increased the total number of root tips to a greater extent than the $P s$ inoculation. It is possible that there was a synergistic effect, as Pseudomonas fluorescens stimulated root growth and MHB activity promoted the formation and establishment of Pisolithus tinctorius mycorrhizae. In turn, the fungus (in association with the rhizobacteria) stimulated growth and branching of the root system. Nevertheless, the root growth potential test (Table 1) illustrated that neither inoculation significantly increased the length of new roots, although a non-significant increase due to the inoculations was observed $(3.3 \mathrm{~cm} /$ plant $v s .1 .9 \mathrm{~cm} /$ plant $)$. Nevertheless, the low sample size selected $(N=9)$ or the low Root Growth Potential test duration (21 days) could cause these non-significant effects on root growth. Even so, other studies have shown the capacity for root regeneration and root protection in plants inoculated with Pseudomonas sp. [23].

Generally, the benefits that the mycorrhizae bring to a host plant are often seen under nutrient-limiting conditions [24]. In several Mediterranean areas, phosphorus is a limiting nutrient during the early stages of growth of P. halepensis [25]; therefore, inoculation with $P S$ could improve the plants' ability to solubilise phosphorus, and thus improve their rate of phosphorus uptake.

In this study, P concentration was significantly decreased by both Pseudomonas and co-inoculation treatments, and $\mathrm{K}$ concentration was significantly decreased by the co-inoculation treatment (Table 1). However, Rincon et al. [26] have observed increases in $\mathrm{P}$ and $\mathrm{K}$ concentrations when Aleppo pine seedlings were inoculated with Pseudomonas fluorescens. However, in this study, the soil did exhibit low nutrient availability due to the use of unfertilised peat as a substrate. We suggest that it was not 
possible to illustrate the effects of $\mathrm{P}$ solubilisation or mobilisation from Pisolithus tinctorius and Pseudomonas fluorescens under these conditions. We suggest that the fungus has a negative effect on the uptake of $\mathrm{K}$ when it is associated with Pseudomonas fluorescens CECT 5281; is it possible that the positive effect of the Pseudomonas strain was lost due during the biotic interaction between the two micro-organisms.

Table 1. Water-relations parameters, growth parameters, nutrient concentration and root growth potential in Pinus halepensis seedlings.

\begin{tabular}{cccc}
\hline Treatment & Control & Pseudomonas & Pisolithus $\times$ Pseudomonas \\
\hline Water-relations parameters & & & \\
$\Psi \pi_{\text {full }}{ }^{1}(\mathrm{MPa})$ & $-1.24( \pm 0.1) \mathrm{a}$ & $-0.43( \pm 0.1) \mathrm{b}$ & $-1.04( \pm 0.14) \mathrm{a}$ \\
$\Psi \pi_{0}(\mathrm{MPa})$ & $-1.72( \pm 0.13) \mathrm{b}$ & $-1.02( \pm 0.33) \mathrm{b}$ & $-2.74( \pm 0.33) \mathrm{a}$ \\
$\mathrm{E}_{\max }(\mathrm{MPa})$ & $11.55( \pm 1.91) \mathrm{a}$ & $5.75( \pm 1.06) \mathrm{b}$ & $3.24( \pm 0.85) \mathrm{b}$ \\
\hline Growth & & & \\
Height $(\mathrm{cm})$ & $6.74( \pm 0.25) \mathrm{b}$ & $8.94( \pm 0.4) \mathrm{a}$ & $9.43( \pm 0.5) \mathrm{a}$ \\
Basal Diameter $(\mathrm{mm})$ & $1.33( \pm 0.07) \mathrm{b}$ & $1.47( \pm 0.06) \mathrm{ab}$ & $1.64( \pm 0.09) \mathrm{a}$ \\
Shoot $(\mathrm{g})$ & $0.137( \pm 0.008) \mathrm{b}$ & $0.268( \pm 0.019) \mathrm{a}$ & $0.3( \pm 0.036) \mathrm{a}$ \\
Root $(\mathrm{g})$ & $0.1( \pm 0.01) \mathrm{c}$ & $0.251( \pm 0.02) \mathrm{a}$ & $0.18( \pm 0.014) \mathrm{b}$ \\
Root growth potential & & & \\
Length ${ }^{2}(\mathrm{~cm})$ & $1.9( \pm 1.1) \mathrm{a}$ & $3.4( \pm 1) \mathrm{a}$ & $3.3( \pm 0.9) \mathrm{a}$ \\
\hline Mycorrhizal colonisation & & & \\
Pisolithus $(\%)$ & $0 \mathrm{~b}$ & $0 \mathrm{~b}$ & $983( \pm 170) \mathrm{a}$ \\
Total ${ }^{3}(\mathrm{~N} / \mathrm{plant})$ & $195( \pm 28) \mathrm{c}$ & $471( \pm 43) \mathrm{b}$ & \\
N $(\mathrm{mg} / \mathrm{g})$ & $6.8( \pm 0.18) \mathrm{a}$ & $7.71( \pm 0.33) \mathrm{a}$ & $7.85( \pm 0.34) \mathrm{a}$ \\
$\mathrm{P}(\mathrm{mg} / \mathrm{g})$ & $0.59( \pm 0.01) \mathrm{a}$ & $0.41( \pm 0.01) \mathrm{b}$ & $0.4( \pm 0.03) \mathrm{b}$ \\
$\mathrm{K}(\mathrm{mg} / \mathrm{g})$ & $6.22( \pm 0.07) \mathrm{a}$ & $6.07( \pm 0.06) \mathrm{a}$ & $5.46( \pm 0.16) \mathrm{b}$ \\
$\mathrm{Ca}(\mathrm{mg} / \mathrm{g})$ & $7.4( \pm 0.51) \mathrm{a}$ & $6.83( \pm 0.1) \mathrm{a}$ & $7.06( \pm 0.22) \mathrm{a}$ \\
$\mathrm{Mg}(\mathrm{mg} / \mathrm{g})$ & $4.33( \pm 0.15) \mathrm{a}$ & $3.72( \pm 0.15) \mathrm{a}$ & $3.83( \pm 0.22) \mathrm{a}$ \\
\hline Nutrient concentration & &
\end{tabular}

\footnotetext{
${ }^{1} \Psi \pi_{\text {full: }}$ osmotic potential at full turgor, $\Psi \pi_{0}$ : osmotic potential at zero turgor and $E_{\text {max }}$ : modulus of elasticity near full turgor; ${ }^{2}$ Total length of new roots/plant; covariate using the height parameter. Values in parentheses represent the standard error. $N=9$ (water-relations, growth, mycorrhizal colonisation and root growth potential parameters); $N=3$ (nutrient parameters). Values in the same row with different letters differ significantly $(P<0.05)$ according to the Duncan test; ${ }^{3}$ Total $=$ number of total root tips/plant.
}

In some cases, the mycorrhizal fungus $\times P$. fluorescens co-inoculation could increase root colonisation by Pseudomonas fluorescens [22] and mycorrhizal fungus. However, the co-inoculation did not affect colonisation of mycorrhizal fungus in other cases, and synergistic effects were observed on plant growth [27]. In this study, it is possible that Pseudomonas fluorescens CECT 5281, in association with Pt, could raise the mycorrhizal colonisation percentage of Pisolithus tinctorius up to $43 \%$, which is a good percentage of mycorrhizae for a seedling nursery. However, in this trial, the data could not be compared with a simple Pt inoculation treatment, although some authors have noted that one MHB can benefit the mycorrhization of certain fungi and negatively impact others [28]. Moreover, 
the mycorrhizae can seriously impact the composition of bacterial communities [29]. Additionally, only Pisolithus tinctorius morphotypes were observed in this analysis.

Based on the results obtained (Table 1), $P S \times P t$ co-inoculation caused an osmotic adjustment at zero turgor $\left(\Psi \pi_{0}\right)$, although inoculation with $P s$ caused the opposite effect, which was a decrease of osmotic potential at full turgor $\left(\Psi \pi_{\text {full }}\right)$. Finally, both inoculations increased the elasticity of the cell tissues, causing an elastic adjustment.

The capacity for osmotic adjustment and the increase in cell wall elasticity (low modulus) are mechanisms traditionally associated with the increased ability of plants to withstand water stress. Through both mechanisms, plants are able to maintain turgor potential, and thereby maintain the capacity for growth and photosynthesis and the ability to tolerate more negative water potentials and lower water content [30]. Specifically, it is possible that $P$. halepensis is unable to make these changes in response to water stress, as some authors have already demonstrated in other species [31]. Other authors have reported changes in the elasticity of cell walls, but not osmotic adjustment [32]; however, based on our results, it appears that Pisolithus tinctorius (in association with Pseudomonas fluorescens CECT 5281) can facilitate osmotic adjustment in Pinus halepensis seedlings. Additionally, two inoculations improved the elasticity of the tissue cells.

Many authors have emphasised that, under semi-arid environmental conditions, the interaction of Pisolithus tinctorius with angiosperms and gymnosperms can reduce the water deficit of the host plant $[10,33]$. Hormonal effects may also be involved in the water stress tolerance of plants inoculated with PGPR, as some bacteria can produce abscisic acid (ABA), which is a phytohormone directly related to plant drought responses [34]. In this study, it appears that Pisolithus tinctorius (in association with Pseudomonas fluorescens CECT 5281) could increase the concentration of active cellular solutes (osmolytes), as evidenced by osmotic adjustment at zero turgor $\Psi \pi_{0}$, thus improving water stress tolerance. However, the effect of Pseudomonas fluorescens CECT 5281 inoculation was the opposite because there was a significant decrease in osmotic potential at full turgor $\left(\Psi \pi_{\text {full }}\right)$, which may have been due to the dilution of cellular osmolytes. In this regard, opposing cell osmotic effects could be seen between Pisolithus tinctorius and Pseudomonas fluorescens. Rincon et al. [26] found that Pseudomonas fluorescens can enhance the Aleppo pine water utilisation when plants undergo a water stress period, although the seedlings were well watered during our study.

Regarding the possible relationship between nutrient concentration and osmolytes, none of the inoculations in this study improved the nutrient concentrations of seedlings; nevertheless, co-inoculation caused an osmotic adjustment, which could have occurred because of Pisolithus tinctorius or possibly because of the synergistic effect of both inocula. In contrast, other authors [35] did not observe any osmotic effect of Pisolithus tinctorius in other forest species.

Potassium is an important solute associated with the regulation of cell turgor and stomatal opening [36]. We observed that co-inoculation decreased $\mathrm{K}$ uptake; however, although the fungus P. tinctorius could reduce the absorption of $\mathrm{K}, P$. tinctorius (in co-inoculation) also facilitated the regulation of cell turgor by osmotic adjustment, perhaps through other mechanisms not dependent on K. Additionnally, although Pseudomonas fluorescens CECT 5281 did not affected the K uptake, it may have caused dilution of active solutes $\left(\Psi_{\pi f u l l}\right)$ in the presence of the fungus (Table 1$)$. Thus, according to the results of this work, it seems that there is no clear relationship between the regulation of cellular osmotic potential and of the $\mathrm{K}$ uptake by plants. 
The simple $P s$ inoculation and the $P S \times P t$ co-inoculation increased cell wall elasticity, causing an elastic adjustment and improving plant tolerance to water stress, thereby allowing the plant to improve its ability to react to possible water changes in the soil ecosystem. However, some authors have suggested that a rigid cell wall may be more effective for maintaining cell and tissue integrity upon re-hydration after a period of stress in species that achieve osmotic adjustment through the accumulation of large amounts of organic solutes [37].

\section{Experimental Section}

\subsection{Plant Production}

The study was conducted at the IFAPA (Centre for Agricultural Research and Training) in La Mojonera, Almeria, Spain. Seeds of Pinus halepensis were collected in 2008 and stored in sealed polyethylene bags at $4{ }^{\circ} \mathrm{C}$ until planting in Forest Pot $300^{\circledR}$ containers $(300 \mathrm{~mL}, 4.6 \times 4.8 \mathrm{~cm}$ at the top section and $1.9 \times 1.9 \mathrm{~cm}$ at the bottom section, $19 \mathrm{~cm}$ depth). For the growth medium (substrate), a mixture of light and dark peat was used for the organic component (Sphagnum moss at pH 6), and vermiculite was used for the inorganic component at a 3:1 ratio (peat:vermiculite). The peat was sterilised by autoclaving at $120^{\circ} \mathrm{C}$ for $2 \mathrm{~h}$.

The seeds were selected after flotation and submergence in distilled water for $24 \mathrm{~h}$ before sowing. Before sowing, all Pinus seeds were surface-disinfested by immersion in $30 \%$ hydrogen peroxide $\left(\mathrm{H}_{2} \mathrm{O}_{2}\right)$ for $15 \mathrm{~min}$, followed by several rinses with distilled water.

In mid April 2008, P. halepensis seeds were sown in 600 cells (12 containers, 50 cells/container). Each cell received 3-8 pine seeds; however, after germination, the plants were thinned so that only one pine seedling remained in each cell. The plantings were conducted in an IFAPA open shade house, and the seedlings were watered daily to saturation at temperatures ranging from 6 to $45^{\circ} \mathrm{C}\left(28{ }^{\circ} \mathrm{C}\right.$ mean) until the inoculations were performed. No fertiliser was added.

\subsection{Fungal and Bacterial Inoculum}

The lyophilized fungal inoculum of Pisolithus tinctorius was purchased from Micología Forestal Aplicada $^{\circledR}$. The spore inoculum was collected in December 2007 from Pinus pinea forests in North Gerona, Spain. After collection, the inoculum was stored at $4{ }^{\circ} \mathrm{C}$ until inoculation. Liquid spore inoculum was prepared by diluting the spore inoculum in distilled water. A concentration of $2.5 \times 10^{4}$ spores $\mathrm{mL}^{-1}$ liquid inoculum was estimated. A lyophilised pre-culture of Pseudomonas fluorescens CECT 5281 (obtained from CECT, Spanish Type Culture Collection, University of Valencia) was stored at $10-15{ }^{\circ} \mathrm{C}$ until inoculation, and it was subjected to 3 successive incubations. A lyophilised pre-culture vial was first suspended in $0.3 \mathrm{~mL}$ of nutritive medium ( $1 \mathrm{~g} \mathrm{~L}^{-1}$ beef extract, $5 \mathrm{~g} \mathrm{~L}^{-1}$ peptone, $5 \mathrm{~g} \mathrm{~L}^{-1} \mathrm{NaCl}$ and $1 \mathrm{~L}$ distilled water, $\mathrm{pH}$ 7.2). A drop $(0.02 \mathrm{~mL})$ of that suspension was added to $5 \mathrm{~mL}$ of nutritive medium and incubated at $30{ }^{\circ} \mathrm{C}$ for $12 \mathrm{~h}$; then it was transferred to $75 \mathrm{~mL}$ of nutritive medium and incubated on an orbital shaker $(200 \mathrm{rpm})$ at $30{ }^{\circ} \mathrm{C}$ for $12 \mathrm{~h}$ After the incubation period, this $80 \mathrm{~mL}$ was added to $720 \mathrm{~mL}$ of nutritive medium and incubated again as before. This final preparation of medium was used as the inoculum. We estimated about $2 \times 10^{9}$ C.F.U.s $\mathrm{mL}^{-1}$ of liquid inoculum [38]. 


\subsection{Experimental Design and Bio-Inoculations}

A three-level (Pseudomonas fluorescens inoculation $[P s]$; Pseudomonas fluorescens $\times$ Pisolithus tinctorius co-inoculation $\left[\begin{array}{lll}P s & \times & P t\end{array}\right]$; and non-inoculated control) unifactorial design distributed randomly in three blocks $(1 \times 3 \times 3)$ with 50 plants per block was utilised (A total of 450 seedlings).

In plants of 2.5 months old, the inocula were applied in the substrata of plants at two time points separated by a period of 15 days (in late June and early July). The substrate of each plant was injected (1 to $5 \mathrm{~cm}$ deep) with Pisolithus tinctorius inoculum $\left(10^{6}\right.$ spores/plant $)$ at $40 \mathrm{~mL} / \mathrm{plant}$ (20 mL/injection) and Pseudomonas fluorescens inoculum $\left(2 \times 10^{10}\right.$ C.F.U.s/plant) at $10 \mathrm{~mL} / \mathrm{plant}$. Finally, 33\% of the seedlings were maintained as controls (non-inoculated).

\subsection{Measurements}

\subsubsection{Pressure-Volume Analysis and Plant Water Measurements}

The pressure-volume curves of the plants (7 months old) were calculated [39,40] during November 2008. These curves were determined using shoot xylem pressure potentials (shoot water potentials) as measured in a pressure chamber [41]. From these graphs, the following water-relation parameters were obtained: (1) the osmotic potential at full turgor $\left(\Psi \pi_{\text {full }}\right),(2)$ the osmotic potential at zero turgor $\left(\Psi \pi_{0}\right)$, and (3) the modulus of elasticity near full turgor $\left(E_{\max }\right)$ [42-45]. Nine seedlings per treatment (three/block) were analyzed, and the plants inoculated with Pisolithus tinctorius were mycorrhizated with Pisolithus tinctorius.

\subsubsection{Growth and Mycorrhizal Colonisation}

Nine plants per treatment (three/block) were randomly chosen. Shoot heights and stem basal diameters were recorded, and mycorrhizal fungal colonisation in the roots was analyzed. After drying at $70{ }^{\circ} \mathrm{C}$ for $48 \mathrm{~h}$, the dry weights of shoots and total root mass were measured.

The ectomycorrhizal fungal colonisation in the roots was analyzed by characterization and identification of the mycorrhizal morphotypes. To achieve this, the whole root system was analysed; the rooted "soil ball" of each of the nine plants was immersed in water several times so that the seedling roots could be carefully freed from most of the substrate in which they had been grown. All roots were cut into pieces approximately $2-3 \mathrm{~cm}$ in length and divided into ectomycorrhizal and non-mycorrhizal tips under a stereomicroscope. All roots showing any of the characteristics indicating ectomycorrhizal infection (blunt tips, altered branching patterns, pigmented mantles, emanating hyphae) were removed for morphotyping. Different features of mycorrhizae were the basis for the identification of ectomycorrhizal morphotypes [46]. The results are given as a percentage of mycorrhizal root tips and total number of root tips/plant. 


\subsubsection{Nutrient Analysis}

The concentration of nitrogen, phosphorus, potassium, calcium, and magnesium in whole plant tissues were determined. In November of 2008, a new random sample of 30 whole plants $(7$ months old) per treatment was divided into three groups (10 plants/block). For each group, the concentrations of phosphorus, potassium, calcium, and magnesium were analyzed using inductively coupled plasma atomic emission spectroscopy (ICP-AES) (Perkin-Elmer model 400) after humid digestion in a microwave with a closed system using concentrated $\mathrm{HNO}_{3}$. Nitrogen was measured with a CHN-600 autoanalyzer.

\subsubsection{Root Growth Potential}

A month before the start of spring (time of onset of forest plantations), in February 2009, nine new plants (10 months old) per treatment (three/block) were randomly chosen. For each plant, the height and basal diameter were measured. Subsequently, each plant was transplanted carefully into a three-litre prismatic pot filled with white perlite. The pots were arranged randomly in the greenhouse and grown for 21 days under optimal environmental conditions in order to facilitate their root growth [47]. For optimal root growth, plants were irrigated daily and the air temperature was maintained between 16 and $22{ }^{\circ} \mathrm{C}$. The relative humidity was maintained at approximately $95 \%$. In March 2009, after 21 days of growth, each plant (11 months old) was extracted, the new roots longer than $1 \mathrm{~cm}$ were counted, and the total length of new roots was measured.

\subsection{Data Analysis}

An analysis of variance (ANOVA) was performed, the means of all the study parameters were calculated, and Duncan multiple-range test was performed at the 0.05 confidence level. In cases where the variance was non-homogeneous, a non-parametric Kruskal-Wallis test was applied. All the statistical analyses were performed using the Statgraphics Plus computer software package (StatPoint Technologies, Inc.). For root growth potential statistical analysis, height and diameter were selected as covariates of the parameters analysed. Similar results were obtained for all covariates, such that only the results obtained against the initial height are presented. Similarly, the results for both parameters examined (number and root length) were similar, so only the results for the length of new roots are presented.

\section{Conclusions}

Despite the complexity of the analysis of microbial interactions in the rhizosphere of forest seedlings, a few major concepts can be deduced. When seedlings of $P$. halepensis are grown under non-limiting nursery conditions, inoculation with Pseudomonas fluorescens CECT 5281 rhizobacteria can promote growth. In some cases, growth promotion occurs without an improvement in P uptake. The Pseudomonas fluorescens CECT 5281 rhizobacteria may have negative osmotic effects on water stress, but it can also improve cell elasticity. In contrast, Pisolithus tinctorius can cause an improvement in cell elasticity and osmotic adjustment when it is associated with Pseudomonas fluorescens. 
These results could be promising for the establishment of Aleppo pine seedlings in reforestation and for enhancing their tolerance to water stress via bio-inoculation of soil microorganisms.

\section{Acknowledgments}

This work has been funded as part of the project A/7844/07 "Biofertilizantes y bioprotectores para la mejora de sistemas agrosilvopastorales". PCI-AECI (Program of cooperation between universities and scientific research between Spain and Latin America. Spanish International Cooperation Agency for Development)

We also appreciate the assistance of the staff and the use of the facilities at the Polytechnic University of Madrid (ETSI Montes and EUIT Forestal, Ma Luz Segura, La Mojonera-IFAPA [Institute of Agricultural Research and Training. Junta de Andalucía], and INIA [National Institute of Agrarian Research]).

\section{Conflicts of Interest}

The authors declare no conflict of interest.

\section{References}

1. Marulanda, A.; Barea, J.M.; Azcon, R. An indigenous drought-tolerant strain of Glomus intraradices associated with a native bacterium improves water transport and root development in Retama sphaerocarpa. Microb. Ecol. 2006, 52, 670-678.

2. Martínez-Ferri, E.; Balaguer, L.; Valladares, F.; Chico, J.M.; Manrique, E. Energy dissipation in drought-avoiding and drought-tolerant tree species at midday during the Mediterranean summer. Tree Physiol. 2000, 20, 131-138.

3. Maestre, F.T.; Cortina, J. Are Pinus halepensis plantations useful as a restoration tool in semiarid Mediterranean areas? For. Ecol. Manag. 2004, 198, 303-317.

4. Caravaca, F.; Alguacil, M.M.; Azcón, R.; Parladé, J.; Torres, P.; Roldán, A. Establishment of two ectomycorrhizal shrub species in a semiarid site after in situ amendment with sugar beet, rock phosphate, and Aspergillus níger. Microb. Ecol. 2005, 49, 73-82.

5. Chanway, C.P. Inoculation of tree roots with plant growth promoting soil bacteria: An emerging technology for reforestation. For. Sci. 1997, 43, 99-112.

6. Rousseau, J.V.D.; Reid, C.P.P.; English, R.J. Relationship between biomass of the mycorrhizal fungus Pisolithus tinctorius and phosphorus uptake in loblolly pine seedlings. Soil Biol. Biochem. 1992, 24, 183-184.

7. Eltrop, L.; Marschner, H. Growth and mineral nutrition of non-mycorrhizal and mycorrhizal Norway spruce (Picea abies) seedlings grown in semi-hydroponic sand culture. I. Growth and mineral nutrient uptake in plants supplied with different forms of nitrogen. New Phytol. 1996, 133, 469-478.

8. Finlay, R.D.; Odham, G.; Söderström, B. Mycelial uptake, translocation and assimilation of nitrogen from $15 \mathrm{~N}$-labelled ammonium by Pinus sylvestris plants infected with four different ectomycorrhizal fungi. New Phytol. 1988, 110, 59-66. 
9. Caravaca, F.; García, C.; Hernández, M.T.; Roldán, A. Aggregate stability changes after organic amendment and mycorrhizal inoculation in the afforestation of a semiarid site with Pinus halepensis. Appl. Soil Ecol. 2002, 19, 199-208.

10. Parke, J.L.; Linderman, R.G.; Black, C.H. The role of ectomycorrhizas in drought tolerance of Douglas fir seedlings. New Phytol. 1983, 95, 83-95.

11. García, C.; Hernández, T.; Roldán, A.; Albadalejo, J.; Castillo, V. Organic amendment and mycorrhizal inoculation as a practice in afforestation of soils with Pinus halepensis Miller: Effect on their microbial activity. Soil Biol. Biochem. 2000, 32, 1173-1181.

12. Bolton, H.J.; Fredickson, J.K.; Elliott, L.F. Microbial Ecology of the Rhizosphere. In Soil Microbial Ecology; Metting, F.B.J., Ed.; Marcel Dekker: New York, NY, USA, 1993; pp. $27-63$.

13. Marschner, P.; Timonen, S. Bacterial Community Composition and Activity in Rhizosphere of Roots Colonized by AMF. In Microbial Activity in the Rhizosphere; Mukerji, K.G., Manoharachary, C., Singh, J., Eds.; Springer-verlag Berlin Heidelberg: Heidelberg, Germany, 2006; pp. 140-154.

14. Matthijs, S.; Tehrani, K.A.; Laus, G.; Jackson, R.W.; Cooper, R.M.; Cornelis, P. Thioquinolobactin, a Pseudomonas siderophore with antifungal and anti-Pythium activity. Environ. Microbiology 2007, 9, 425-434.

15. Arshad, M.; Shaharoona, B.; Mahmood, T. Inoculation with Pseudomonas spp. containing ACC-Deaminase partially eliminates the effects of drought stress on growth, yield, and ripening of pea (Pisum sativum L.). Pedosphere 2008, 18, 611-620.

16. Deveau, A.; Palin, B.; Delaruelle, C.; Peter, M.; Kohler, A.; Pierrat, J.C.; Sarniguet, A.; Garbaye, J.; Martin, F.; Frey-Klett, P. The mycorrhiza helper Pseudomonas fluorescens BBc6R8 has a specific effect on the growth, morphology and gene expression of the ectomycorrhizal fungus Laccaria bicolour S238N. New Phytol. 2007, 175, 743-755.

17. Frey-Klett, P.; Garbaye, J.; Tarkka, M. The Mycorrhiza helper bacteria revisited. New Phytol. 2007, 176, 22-36.

18. Heinonsalo, J.; Frey-Klett, P.; Pierrat, J.C.; Churin, J.L.; Vairelles, J.; Garbaye, J. Fate, tree growth effect and potential impact on soil microbial communities of mycorrhizal and bacterial inoculation in a forest plantation. Soil Biol. Biochem. 2004, 36, 211-216.

19. Roldán, A.; Querejeta, I.; Albaladejo, J.; Castell, V. Survival and growth of Pinus halepensis Miller seedlings in a semi-arid environment after forest soil transfer, terracing and organic amendments. Ann. For. Sci. 1996, 53, 1099-1112.

20. Probanza, A.; Mateos, J.L.; Lucas, G.J.A.; Ramos, B.; de Felipe, M.R.; Gutierrez, M.F.J. Effects of inoculation with PGPR Bacillus and Pisolithus tinctorius on Pinus pinea L. growth, bacterial rhizosphere colonization, and mycorrhizal infection. Microb. Ecol. 2001, 41, 140-148.

21. Founoune, H.; Duponnois, R.; Meyer, J.M.; Ba, A.M.; Chotte, J.L.; Neyra, M. Interactions between ectomycorrhizal symbiosis and Pseudomonas fluorescens on Acacia holosericea: Isolation of mycorrhization helper bacteria (MHB) from a soudano-sahelian soil. FEMS Microbiol. Ecol. 2002, 41, 37-46. 
22. Ouahmane, L.; Revel, J.C.; Hafidi, M.; Thioulouse, J.; Prin, Y.; Galiana, A.; Dreyfus, B.; Duponnois, R. Responses of Pinus halepensis growth, soil microbial catabolic functions and phosphate-solubilizing bacteria after rock phosphate amendment and ectomycorrhizal inoculation. Plant Soil 2009, 320, 169-179.

23. Deka Boruah, H.P.; Dileep Kumar, B.S. Biological activity of secondary metabolites produced by a strain of Pseudomonas fluorescens. Folia Microbiol. 2002, 47, 359-363.

24. Smith, S.E.; Read, D.J. Mycorrhizal Symbiosis, 2nd ed.; Academic Press: London, UK, 1997; p. 605 .

25. Sardans, J.; Rodá, F.; Peñuelas, J. Effects of a nutrient pulse supply on nutrient status of the Mediterranean trees Quercus ilex subsp. ballota and Pinus halepensis on different soils and under different competitive pressure. Trees 2006, 20, 619-632.

26. Rincón, A.; Valladares, F.; Gimeno, T.E.; Pueyo, J.J. Water stress responses of two Mediterranean tree species influenced by native soil microorganisms and inoculation with a plant growth promoting rhizobacterium. Tree Physiol. 2008, 28, 1693-1701.

27. Rincón, A.; Ruiz-Díez, B.; García-Fraile, S.; Lucas-García, J.A.; Fernández-Pascual, M.; Pueyo, J.J.; de Felipe, M.R. Colonization of Pinus halepensis roots by Pseudomonas fluorescens and interaction with the ectomycorrhizal fungus Suillus granulatus. FEMS Microbiol. Ecol. 2005, 51, 303-311.

28. Tarka, M.T.; Frey-Klett, P. Mycorrhiza helper bacteria. In Mycorrhiza; Varma, A., Ed.; Springer-Verlag Berlin Heidelberg: Heidelberg, Germany, 2008; pp. 113-132.

29. Barea, J.M. Mycorrhiza/Bacteria Interactions on Plant Growth Promotion. In Plant Growth Promoting Rhizobacteria, Present Status and Future Prospects; Ogoshi, A., Kobayashi, L., Homma, Y., Kodama, F., Kondon, N., Akino, S., Eds.; OCDE: Paris, France, 1997; pp. 150-158.

30. Villar-Salvador, P.; Caña, L.; Peñuelas, J.; Carrasco, I.; Domínguez, S.; Renilla, I. Relaciones hídricas y potencial de formación de raíces en plántulas de Pinus halepensis Mill. sometidas a diferentes niveles de endurecimientos por estrés hídrico. Monographs Spanish Soc. For. Sci. 1997, 4, 81-92.

31. Abrams, M.D.; Kubiscke, M.E. Synchronous changes in tissue water parameters of mature foliage from well-watered and periodically droughted tree seedlings. J. Exp. Bot. 1994, 45, 171-177.

32. Stewart, J.D.; Lieffers, V.J. Preconditioning effects of nitrogen relative addition rate and drought stress on container-grown lodgepole pine seedlings. Can. J. For. Res. 1993, 23, 1663-1671.

33. Lamhamedi, M.S.; Bernier, P.Y.; Fortín, J.A. Growth, nutrition and response to water stress of Pinus pinaster inoculated with ten dikaryotic strains of Pisolithus sp. Tree Physiol. 1992, 10, 153-167.

34. Boiero, L.; Perrig, D.; Masciarelli, O.; Pena, C.; Cassán, F.; Luna, V. Phytohormone production by strains of Bradyrhizobium japonicum and possible physiological and technological implications. Appl. Microbiol. Biotechnol. 2007, 74, 874-880.

35. Alberdi, M.; Alvarez, M.; Valenzuela, E.; Godoy, R.; Olivares, E.; Barrientos, M. Response to water deficit of Nothofagus dombeyi plants inoculated with a specific (Descolea antarctica Sing) and non-specific (Pisolithus tinctorius (Pers.) Coker \& Couch) ectomycorrhizal fungi. Rev. Chil. Hist. Nat. 2007, 80, 479-491. 
36. Benlloch-González, M.; Arquero, O.; Fournier, J.M.; Barranco, D.; Benlloch, M. $\mathrm{K}^{+}$starvation inhibits water-stress-induced stomatal closure. J. Plant Physiol. 2008, 165, 623-630.

37. Patakas, A.; Nikolaou, N.; Zioziou, K.; Radoglou, K.; Noitsakis, B. The role of organic solute and ion accumulation in osmotic adjustment in drought-stressed grapevines. Plant Sci. 2002, 163, 361-367.

38. Miles, A.A.; Misra, S.S. The estimation of the bactericidal power of the blood. J. Hyg. 1938, 38, 732-749.

39. Tyree, M.; Hammel, H.T. The measurement of the turgor pressure and the water relations of plants by the pressure technique. J. Exp. Bot. 1972, 23, 267-282.

40. Robichaux, R.H. Variation in the tissue water relations of two sympatric Hawaiian Dubautia species and their natural hybrid. Oecologia Berlin 1984, 65, 75-81.

41. Scholander, P.F.; Hammel, H.T.; Bradstreet, E.D.; Hemmingsen, E.A. Sap pressure in vascular plants. Science 1965, 148, 339-346.

42. Cheung, Y.N.S.; Tyree, M.T.; Dainty, J. Water relations parameters on single leaves obtained in a pressure bomb and some ecological interpretations. Can. J. Botany 1975, 53, 1342-1346.

43. Jones, M.M.; Turner, N.C. Osmotic adjustment in expanding and fully expanded leves of sunlower in response to water deficits. Aust. J. Plant Physiol. 1980, 7, 181-192.

44. Tyree, M.; Jarvis, P.G. Water in tissues and cells. In Encyclopedia of Plant Physiology, New Series, Physiological Plant Ecology II; Lange, O.L., Nobel, P.S., Osmond, C.B., Ziegler, H., Eds.; Springer-verlag Berlin Heidelberg: Heidelberg, Germany, 1982; Volume 12B, pp. 36-77.

45. Bowman, W.D.; Roberts, S.W. Seasonal changes in tissue elasticity in chaparral shrubs. Physiol. Plant. 1985, 65, 233-236.

46. Colour Atlas of Ectomycorrhizae, 1st-11th ed.; Agerer, R., Ed.; Einhorn: Schwäbisch Gmünd, Germany, 1987-1998.

47. Burdett, A.N. Understanding root growth capacity: Theoretical considerations in assessing planting stock quality by means of root growth tests. Can. J. For. Res. 1987, 17, 768-775.

(C) 2013 by the authors; licensee MDPI, Basel, Switzerland. This article is an open access article distributed under the terms and conditions of the Creative Commons Attribution license (http://creativecommons.org/licenses/by/3.0/). 